\title{
The Reality of Practicing the Policy of Additional Educational Support Needs among Teachers of Deaf Students in Qatar
}

\author{
Khaled Yousef Asi \\ Assist. Professor of Special Education, College of Social Sciences \\ Al-Imam Muhammad Ibn Saud Islamic University \\ Email: khaled-asi@hotmail.com
}

Received: July 14, 2016 Accepted: August 15, 2016 Published: September 04, 2016

doi:10.5296/ijld.v6i3.9980 URL: http://dx.doi.org/10.5296/ ijld.v6i3.9980

\begin{abstract}
The present study aimed to identify the reality of practicing the policy of additional educational support needs among teachers of deaf students in Qatar according to the variables of gender, years of experience and academic stage. The sample consisted of (55) teachers who were randomly selected from Audio Education Complex in the city of Doha, Qatar. The questionnaire used as an instrument for data collection process. The results showed that the reality of practicing the policy of additional educational support needs among teachers of deaf students in Qatar was high, and the results showed statistically significant differences in the two domains, school policy and the team in charge, and in the total degree of the reality of practicing the policy of additional educational support needs among teachers of deaf students due to the impact of gender in favor of males, while no statistical differences due to the variables of years of experience and academic stage. The study recommended the need to educate teachers of deaf students on the importance of utilizing additional educational support needs in the education of the deaf for its apparent role in activating the partnership with a multi-disciplinary team as well as parents of deaf students.
\end{abstract}

Keywords: Teachers of deaf students, Additional educational support, Qatar 


\section{Introduction}

Countries all over the world consistently tried to provide all educational support and do their best through educational institutions to get excellent educational outcomes as the progress of nations and peoples stems from education in its various fields. These countries sought for the latest in the world of knowledge and skill to reach the highest degree of quality of education; there is no doubt that using of advanced educational strategies and policy is effective and successful step.

The educational institution achieves its goals if it succeeds in providing an appropriate level of accommodation and compatibility between teacher and student and between the student and the curriculum, because it allows students better conditions for the growth of cognitive, social and emotional development (Attya, 2001).

The Education Authority at the Supreme Council of Education in Qatar has stressed the importance of finding an appropriate and supportive learning environment, paying attention to improve the academic level of all those with learning disabilities, and to provide these groups with academic and social experience in ways that fit their abilities and their energies and take into account individual differences. The negative impact on learning disability emerges in the deaf child so he needs special methods for teaching and (Issa, 2001). Recent educational practices and rapid developments depends on many factors, including the provision of professional development for teaching staff and their knowledge of the services that support them in the performance of their duties skillfully (Hallahan, Kuffman and Marteinez, 2005), where this is consistent with their attitudes and encourage them to be creative in the work and research on successful experiences in the field (Lablanc, Richardson \&Melntosh, 2005)

Al-Rayes (2006) confirmed that deaf education has witnessed a great furore, which is due to many factors including the method of communication and delivery of information to them. Rifai(2005) also indicated the low level of cognitive skills and qualifications of vocational awareness among teachers of deaf children.

The Supreme Education Council (SEC) in Qatar adopted applying the policy of additional educational support needs to educational environments in order to provide the desired support level and achieve quality in education and access to a full inclusion, it is a policy that calls for improving the quality of teaching and learning provided to persons with disabilities in general, including those with hearing disabilities in order to create learning environment to accommodate all students, regardless of their abilities, thus achieving the principle of education for all, where keen communities are seeking to the full inclusion system for students with learning difficulties as the additional educational support policy is based on conducting survey process to the level of student performance to determine the level of support required for the three levels, through a variety of domains such as: school policy, team in charge, the curriculum, professional development, and school support for the family and the student (Supreme Education Council of Qatar, 2009).

The concept of additional educational support needs has witnessed great interest within the 
policy of the State of Qatar in the field of education in order to enable schools to provide a supportive learning environment and an opportunity for all students to acquire the outstanding educational experience and high quality by taking into account individual differences.

The principle of entitlement encompasses the rights of all students to access the same educational experience as their peers; to participate in all school activities and to achieve their full potential. Inclusive education also seeks to maximize the participation of all learners in the full life of their local school. Furthermore, it seeks to make learning experiences relevant and meaningful for all students.

Inclusive education is a process of enabling all students to learn and participate effectively within mainstream schooling systems and in mainstream classrooms. Placing previously excluded students within a mainstream setting, however, does not of itself achieve inclusion. Whole school policies and practice need to result in the development of agreed strategies for ensuring that inclusion is achieved in an effective way, enabling all students to access the full range of curriculum opportunities and experiences.

Committing to the fundamental principles of the two concepts of Merit: Education for All and Inclusive Education to ensure the right of all students to get and enjoy the same educational experiences of others and doubling the level of participation of all learners in the school environment, as confirmed by the international and local legislation for the rights of people with disabilities (Angelides and Aravi, 2007).

Focusing on applying the policy of additional educational support needs, the Supreme Education Council of Qatar gradually applies the principle of education for all, where this policy is based on a sequential system within various and integrated stages as shown in the Supreme Education Council of Qatar (Supreme Education Council of Qatar, 2009):

\subsection{School Self-review}

This stage aims to provide the school with a tool to enable the school to ensure the effectiveness of the strategies and methods adopted in additional educational support process among students, it consists of several domains such as: school policy, the team in charge, the school curriculum, professional development, school support for the family and the student. These domains include a large number of real practice indicators for the educational support that help the student receive educational support through a comprehensive approach providing him/her an opportunity to engage with a broad range of educational experiences enjoyed by his/her classmates.

\subsection{Response to intervention}

It is the stage of continuous assessment of the student, where the school keeps the student's academic file from the first school day, including all the years studied, gradual plans for improvement and achieving educational and training goals that were previously planned. The new hired teacher can follow-up the ex-teachers as the model illustrates the strengths and weaknesses of student in classroom courses and the extent of his need for support by defining 
what is called the level of support required, which divided into three levels from the first to third; and support requirements intensely increase whenever we moved from the first level to the second level or third level.

\subsection{Arrangements and facilities}

This stage is a direct strategy and method that provides an opportunity for students to receive educational subject in a manner appropriate for their abilities and energies; this stage represents adaptation and modification process for the curriculum and compatibility between the curriculum and the abilities of the student.

Additional educational support team consists of the principal, the academic director, and coordinator of the additional educational support, parents, course coordinator, course teacher, assistant teacher, technology specialist, psychological specialist, social specialist, early intervention specialist, speech and language specialist, and other specialists according group's requirements and the characteristics of the case (Luckner, et. al, 2005).

Additional educational support can be defined as an educational policy with educational, cultural and legislative objectives, through several practical stages including the self-review stage that provides the necessary practices, and response to intervention that determines the required level for learner support and the stage of arrangements and facilities that provides educational experiences suitable for the abilities and characteristics of the learner (Supreme Education Council of Qatar, 2009). Combs (2004) showed that the educational support is the educational activity presented to the learner at any time of the teaching-learning process, and aims to provide assistance to immature or low-achievement learners who face obstacles in their learning. Lipscomb, et al (2004) defined Education by support as immediate assistance to students so they can complete a task or skill that cannot be achieved on their own, it is a temporary support process that gradually disappears to get the student into independence and self-organization of learning.

The researcher of the present study, worked as a coordinator of additional educational support, found that the additional educational support activity is pedagogical educational targeting the low-achievers who could not take advantage of the required scientific material/course through the educational learning process, which is an organized and planned mechanism for a variety of methods, strategies and stages involved in levels of support according to the capacities and needs of learners with disabilities.

Due to the characteristics of deaf students, teaching for the deaf requires ad hoc teaching through using modified teaching aids and methods, and more flexible classroom practices with the investment of their strengths to enable them to learn; the modification includes: teaching methods, learning environment, school curricula, instructional techniques and technologies, and methods of assessment (Aqel, 2012).

Several pieces of literature review demonstrated the importance of additional support in the education of the deaf, where Al-Nahas (2004) assured the importance of employing computers in education of the deaf. Al-Rashidi and Al-Ziq (2009) indicated the existence of a variety of training needs related to the teaching competencies necessary for science teachers 
in middle school for the deaf. Taylor, et al (2008) pointed out the need for competence on the part of teachers of the deaf with respect to additional services and education strategies and methods.

Sedeeq (2010) confirmed that teachers of deaf students are different in their training needs, and there are statistically significant differences between the female teachers of the deaf in the competences of teaching the subject of reading due to the variable of experience in favor of the most experienced. Issa and Obaydat (2010) emphasized on the effectiveness of a rehabilitation program for improving the level of the skill of auditory discrimination and auditory memory among the deaf. Cannon (2010) proved the effectiveness of additional educational computerized program to improve language skills and expressive language skills among deaf children.

Morsi (2013) showed that the computer programs contribute to the improvement of academic achievement among the hearing-impaired students.

\section{Statement of the Problem}

Appropriate educational institutions in the field of special education provides many of the proposals, programs and policies to achieve comprehensive inclusion and the principle of equal opportunities through the realization of the principle of education for all, and no doubt that the negative impact of disability on the level of educational performance and academic achievement motivates us to look for strategies and supportive policies for them. Learners with disabilities are allowed to engage in a wide range of educational experiences through adopting the policy of additional educational support needs as a global educational policy. This policy can be applied through the stages of additional educational support that offer educational subject in various methods to enable them to learn like their normal peers after determining the required support level through applying the stages of additional educational support, including school self-review, response to intervention for identifying the strengths and weaknesses, and then arrangements and facilities as a direct application of what has been reached, this study sought to answer the following questions:

1. What is the reality of practicing the policy of additional educational support needs among the teachers of deaf students in Qatar?

2. Are there any significant differences $(a=0.05)$ in the reality of practicing the policy of additional educational support needs among the teachers of deaf students in Qatar due to the variable of gender?

3. Are there any significant differences $(a=0.05)$ in the reality of practicing the policy of additional educational support needs among the teachers of deaf students in Qatar due to years of experience?

4. Are there any statistically significant differences $(a=0.05)$ in the reality of practicing the policy of additional educational support needs among the teachers of deaf students in Qatar due to education stage? 


\section{Significance}

- This study derives its importance from the additional educational support policy and the impact of practicing on the education of the deaf as an important step in achieving comprehensive inclusion and realization of the principle of education for all,so this study is expected to contribute to the spread of additional educational support policy that was approved and accredited by international educational institutions as being adopted in Qatar.

- This study may benefit specialists, officials and decision-makers in the global educational institutions through adopting the policy of additional educational support needs in the education of students with disabilities; paving the way for the countries applying this policy to improve the decentralization plan, the application of comprehensive inclusive education and achieving the principle of education for all.

\section{Objectives}

The present study aimed to:

1. Identify the reality of practicing the policy of additional educational support needs among teachers of deaf students in Qatar.

2. Detect differences in the reality of practicing the policy of additional educational support needs among teachers of deaf students in Qatar due to the various variables of gender, stage of education and years of experience.

\section{Methodology}

The descriptive survey approach utilized in the current study, which qualitatively and quantitatively describes the reality by answering questions about the status quo using a questionnaire of the reality of practicing the policy of additional educational support needs among teachers of deaf students.

\subsection{Population and Sampling}

The study population consisted of all teachers in audio education complex in the city of Doha, Qatar's numbered (80) teachers for the second semester of the academic year 2014/2015. The study sample consisted of (55) teachers who randomly selected and distributed according to the study variables: gender, years of experience and academic stage, as shown in table (1).

Table (1): Sample distribution according to variables

\begin{tabular}{|l|l|l|l|}
\hline Variables & Categories & Frequencies & Percentage \\
\hline \multirow{2}{*}{ Gender } & Male & 28 & 50.9 \\
\cline { 2 - 4 } & Female & 27 & 49.1 \\
\hline
\end{tabular}




\begin{tabular}{|l|l|l|l|}
\hline \multirow{4}{*}{$\begin{array}{l}\text { Years } \\
\text { Experience }\end{array}$} & $(1-3)$ & 18 & 32.7 \\
\cline { 2 - 4 } & $(4-7)$ & 27 & 49.1 \\
\cline { 2 - 4 } & More than 7 years & 10 & 18.2 \\
\hline \multirow{3}{*}{ Academic stage } & Primary & 20 & 36.4 \\
\cline { 2 - 4 } & Prep & 16 & 29.1 \\
\cline { 2 - 4 } & High school & 19 & 34.5 \\
\hline & Total & 55 & 100.0 \\
\hline
\end{tabular}

\subsection{Instrument}

A questionnaire developed in this study to measure the reality of practicing the policy of additional educational support needs among teachers of deaf students in Qatar, based mainly on "Additional Educational Support Needs " issued by the Supreme Education Council of Qatar (Supreme Education Council of Qatar, 2009) for determining the dimensions and drafting of paragraphs. After verifying its validity and reliability, the final draft of the instrument consisted of (41) paragraphs/items distributed to five domains: school policy (1-9) paragraphs, the team in charge (10-17), school curriculum (18-25), professional development (26-32), and the school support for the family and the student (33-41). The responder checks in front of each paragraph of domains on a scale of four rates (always, often, sometimes and rarely) for the following weights, respectively $(4,3,2$, and 1).

\subsection{Validity}

To verify the validity of the questionnaire, the first draft was reviewed and evaluated by ten reviewers, more experienced in special education, psychology and measurement and evaluation in Jordanian Universities, where they were asked to check the appropriateness of the paragraphs (items) and to make sure of the language and the appropriateness of the instrument to achieve the study objectives. In light of the views and suggestions of the evaluators, the required modifications were made with agreement percentage (80\%), and the final draft consisted of (41) paragraphs.

\subsection{Reliability}

The reliability of the questionnaire was verified by the method of (test-retest), where the questionnaire applied to a pilot sample numbered (20) teachers with two weeks interval between first and second application/test. Pearson correlation coefficient was calculated between the scores of respondents and the total reliability coefficient of the instrument was (0.90). The second method conducted by calculating of the internal consistency coefficient (Cronbach's Alpha) of the instrument $=(0.95)$. These are considered appropriate values for 
achieving the objectives of the study.

Table (2): Test-retest coefficients and Cronbach's Alpha to the domains of the study

\begin{tabular}{|l|l|l|}
\hline Domains & Retest Reliability & $\begin{array}{l}\text { Cronbach's } \\
\text { Alpha }\end{array}$ \\
\hline School policy & 0.91 & .84 \\
\hline Team in charge & 0.93 & .85 \\
\hline Curriculum & 0.90 & .87 \\
\hline Professional development & 0.89 & .78 \\
\hline School support for family and student & 0.92 & .79 \\
\hline
\end{tabular}

\subsection{Correction for instrument response}

As mentioned above, the given grades (4, 3, 2 and 1) set for the four alternatives, where (4) for always, (3) for often, (2) for sometimes, and (1) for rarely, the instrument grades ranged from the least score (41) to the highest one (164). To evaluate and judge the level of the arithmetic mean of the domains and the total instrument, the statistical standard adopted:

From (1.00 - 1.99)is (low)

$\operatorname{From}(2.00-2.99)$ is (medium)

From (3.00- 4.00) is(high)

Thus, the scale has been calculated by using the following equation:

Instrument maximum (4) - Instrument minimum (1)

The required number of categories (3)

$$
4-1 / 3=1.00
$$

Then, (1.00) was added to the end of each category.

\section{Results}

\subsection{Results of the first question}

What is the reality of practicing the policy of additional educational support needs among the teachers of deaf students in Qatar? To answer this question, arithmetic means and standard deviations calculated for the reality of practicing the policy of additional educational support needs among teachers of deaf students in Qatar, as illustrated in table (3).

Table (3): Means and Standard Deviations in descending order 


\begin{tabular}{|c|c|c|c|c|c|}
\hline Rank & No. & Domain & Mean & St. D & Level \\
\hline 1 & 2 & Team in charge & 3.61 & 0.41 & High \\
\hline 2 & 4 & Professional development & 3.61 & 0.38 & High \\
\hline 3 & 1 & School policy & 3.57 & 0.38 & High \\
\hline 4 & 3 & Curriculum & 3.54 & 0.44 & High \\
\hline 5 & 5 & $\begin{array}{l}\text { School support for family and } \\
\text { student }\end{array}$ & 3.54 & 0.36 & High \\
\hline \multicolumn{3}{|l|}{ Total } & 3.57 & 0.36 & High \\
\hline
\end{tabular}

Table (3) shows that the means ranged from (3.54-3.61) and standard deviations (0.36 - 0.44), where the domain of team in charge got the first place with the highest arithmetic mean (3.61) and standard deviation (0.41) and the reality of the practice was at a high level; followed by the second domain of professional development with a mean (3.61) and a standard deviation (0.38) and the reality of the practice was at a high level. While the domain of school support for the family and the student ranked the fifth place with a mean (3.54) and a standard deviation (0.36) and the reality of the practice was at a high level. The arithmetic mean of the total instrument was (3.57) and a standard deviation (0.36), the reality of the practice was at a high level. It is concluded that the reality of practicing the policy of additional educational support needs among teachers of deaf students in Qatar is high.

\subsection{Results of the second question}

Are there any significant differences $(a=0.05)$ in the reality of practicing the policy of additional educational support needs among the teachers of deaf students in Qatar due to the variable of gender? To answer this question, arithmetic means and standard deviations calculated for the reality of practicing the policy of additional educational support needs among teachers of deaf students in Qatar due to the variable of gender, and to indicate the statistical differences between the arithmetic means, T-test was use, as shown in table (4). 


\section{Macrothink}

International Journal of Learning and Development ISSN 2164-4063 2016, Vol. 6, No. 3

Table (4): Means, standard deviations and T-test for the impact of gender on the reality of practicing the policy of additional educational support needs among teachers of deaf students in Qatar

\begin{tabular}{|c|c|c|c|c|c|c|c|}
\hline Domains & Gender & No. & Mean & St. D & T-value & $\begin{array}{l}\text { D. } \\
\text { freedom }\end{array}$ & $\begin{array}{l}\text { Sig. } \\
\text { level }\end{array}$ \\
\hline \multirow[t]{2}{*}{ School policy } & Male & 28 & 3.69 & .210 & \multirow[t]{2}{*}{2.543} & \multirow[t]{2}{*}{53} & \multirow[t]{2}{*}{.014} \\
\hline & Female & 27 & 3.44 & .466 & & & \\
\hline \multirow[t]{2}{*}{ Team in charge } & Male & 28 & 3.74 & .152 & \multirow[t]{2}{*}{2.628} & \multirow[t]{2}{*}{53} & \multirow[t]{2}{*}{.011} \\
\hline & Female & 27 & 3.47 & .529 & & & \\
\hline \multirow[t]{2}{*}{ Curriculum } & Male & 28 & 3.65 & .317 & \multirow[t]{2}{*}{1.818} & \multirow[t]{2}{*}{53} & \multirow[t]{2}{*}{.075} \\
\hline & Female & 27 & 3.44 & .526 & & & \\
\hline \multirow{2}{*}{$\begin{array}{l}\text { Professional } \\
\text { development }\end{array}$} & Male & 28 & 3.69 & .210 & \multirow[t]{2}{*}{1.699} & \multirow[t]{2}{*}{53} & \multirow[t]{2}{*}{.095} \\
\hline & Female & 27 & 3.52 & .486 & & & \\
\hline \multirow{2}{*}{$\begin{array}{l}\text { School support for } \\
\text { family and student }\end{array}$} & Male & 28 & 3.60 & .223 & \multirow[t]{2}{*}{1.298} & \multirow[t]{2}{*}{53} & \multirow[t]{2}{*}{.200} \\
\hline & Female & 27 & 3.48 & .460 & & & \\
\hline \multirow[t]{2}{*}{ Total } & Male & 28 & 3.67 & .157 & \multirow[t]{2}{*}{2.204} & \multirow[t]{2}{*}{53} & \multirow[t]{2}{*}{.032} \\
\hline & Female & 27 & 3.47 & .467 & & & \\
\hline
\end{tabular}

Table (4) indicates that there are statistically significant differences $(a=0.05)$ due to the impact of gender in the two domains of school policy and team in charge of and in the total score, where differences were in favor of males, with no differences in other domains.

\subsection{Results related to the third question}

Are there any significant differences $(\mathrm{a}=0.05)$ in the reality of practicing the policy of additional educational support needs among the teachers of deaf students in Qatar due to years of experience? To answer this question, arithmetic means and standard deviations calculated for the reality of practicing the policy of additional educational support needs among teachers of deaf students in Qatar due to years of experience, as shown in table (5). 
Table (5): Means and standard deviations for the impact "years of experience"

\begin{tabular}{|c|c|c|c|c|}
\hline Domains & Categories & No. & Mean & St. D \\
\hline \multirow[t]{4}{*}{ School policy } & $(1-3)$ & 18 & 3.69 & .189 \\
\hline & $(4-7)$ & 27 & 3.50 & .489 \\
\hline & $\begin{array}{l}\text { More than } 7 \\
\text { years }\end{array}$ & 10 & 3.51 & .217 \\
\hline & Total & 55 & 3.57 & .377 \\
\hline \multirow[t]{4}{*}{ Team in charge } & $(1-3)$ & 18 & 3.73 & .098 \\
\hline & $(4-7)$ & 27 & 3.54 & .551 \\
\hline & $\begin{array}{l}\text { More than } 7 \\
\text { years }\end{array}$ & 10 & 3.58 & .222 \\
\hline & Total & 55 & 3.61 & .406 \\
\hline \multirow[t]{4}{*}{ Curriculum } & $(1-3)$ & 18 & 3.56 & .330 \\
\hline & $(4-7)$ & 27 & 3.55 & .536 \\
\hline & $\begin{array}{ll}\text { More than } 7 \\
\text { years }\end{array}$ & 10 & 3.50 & .363 \\
\hline & Total & 55 & 3.54 & .442 \\
\hline \multirow[t]{4}{*}{$\begin{array}{l}\text { Professional } \\
\text { development }\end{array}$} & $(1-3)$ & 18 & 3.67 & .183 \\
\hline & $(4-7)$ & 27 & 3.58 & .496 \\
\hline & $\begin{array}{l}\text { More than } 7 \\
\text { years }\end{array}$ & 10 & 3.56 & .265 \\
\hline & Total & 55 & 3.61 & .378 \\
\hline School support to & $(1-3)$ & 18 & 3.63 & .175 \\
\hline
\end{tabular}




\begin{tabular}{|l|l|l|l|l|}
\hline family and student & & & & \\
\hline & $(4-7)$ & 27 & 3.49 & .485 \\
\hline & $\begin{array}{l}\text { More than } 7 \\
\text { years }\end{array}$ & 10 & 3.52 & .158 \\
\hline Total & Total & 55 & 3.54 & .362 \\
\hline & $(1-3)$ & 18 & 3.66 & .113 \\
\hline & $(4-7)$ & 27 & 3.53 & .487 \\
\hline & $\begin{array}{l}\text { More than } 7 \\
\text { years }\end{array}$ & 10 & 3.53 & .192 \\
\hline & Total & 55 & 3.57 & .358 \\
\hline
\end{tabular}

Table (5) shows variance in the means and standard deviations for the reality of practicing the policy of additional educational support needs among teachers of deaf students in Qatar because of the different categories of the variable of years of experience; and to indicate the significance of statistical differences between the arithmetic means, one-way analysis of variance was used, as reveled in table (6).

Table (6): One-way variance analysis for the impact of years of experience

\begin{tabular}{|l|l|l|l|l|l|l|}
\hline Domains & Source & $\begin{array}{l}\text { Sum of } \\
\text { Squares }\end{array}$ & $\begin{array}{l}\text { D. } \\
\text { freedom } \\
\text { s }\end{array}$ & $\begin{array}{l}\text { Mean of } \\
\text { squares }\end{array}$ & F-value & Sig. level \\
\hline School policy & $\begin{array}{l}\text { Between } \\
\text { groups }\end{array}$ & .423 & 2 & .212 & 1.521 & .228 \\
\cline { 2 - 8 } & $\begin{array}{l}\text { Within } \\
\text { groups }\end{array}$ & 7.238 & 52 & .139 & & \\
\cline { 2 - 8 } Team in charge & $\begin{array}{l}\text { Total } \\
\text { Between } \\
\text { groups }\end{array}$ & 7.661 & 54 & 293 & \\
\cline { 2 - 8 } & $\begin{array}{l}\text { Within } \\
\text { groups }\end{array}$ & 8.508 & 52 & .164 & .206 & \\
\hline
\end{tabular}




\begin{tabular}{|c|c|c|c|c|c|c|}
\hline & Total & 8.919 & 54 & & & \\
\hline \multirow{3}{*}{ Curriculum } & $\begin{array}{l}\text { Between } \\
\text { groups }\end{array}$ & .026 & 2 & .013 & .063 & .939 \\
\hline & $\begin{array}{l}\text { Within } \\
\text { groups }\end{array}$ & 10.512 & 52 & .202 & & \\
\hline & Total & 10.538 & 54 & & & \\
\hline \multirow[t]{3}{*}{$\begin{array}{l}\text { Professional } \\
\text { development }\end{array}$} & $\begin{array}{l}\text { Between } \\
\text { groups }\end{array}$ & .106 & 2 & .053 & .361 & 699 \\
\hline & $\begin{array}{l}\text { Within } \\
\text { groups }\end{array}$ & 7.607 & 52 & .146 & & \\
\hline & Total & 7.713 & 54 & & & \\
\hline \multirow{3}{*}{$\begin{array}{l}\text { School support } \\
\text { to family and } \\
\text { student }\end{array}$} & $\begin{array}{l}\text { Between } \\
\text { groups }\end{array}$ & .216 & 2 & .108 & .820 & .446 \\
\hline & $\begin{array}{l}\text { Within } \\
\text { groups }\end{array}$ & 6.847 & 52 & .132 & & \\
\hline & Total & 7.063 & 54 & & & \\
\hline \multirow[t]{3}{*}{ Total } & $\begin{array}{l}\text { Between } \\
\text { groups }\end{array}$ & .194 & 2 & .097 & .750 & .477 \\
\hline & $\begin{array}{l}\text { Within } \\
\text { groups }\end{array}$ & 6.721 & 52 & .129 & & \\
\hline & Total & 6.914 & 54 & & & \\
\hline
\end{tabular}

Table (6) demonstrates that there are no statistically significant differences at the significance level $(\mathrm{a}=0.05)$ in the reality of practicing the policy of additional educational support needs among teachers of deaf students in Qatar due to years of experience in all domains and in the total instrument.

\subsection{Results of the fourth question}

Are there any statistically significant differences $(a=0.05)$ in the reality of practicing the policy of additional educational support needs among the teachers of deaf students in Qatar 
due to education stage? To answer this question, arithmetic means and standard deviations calculated for the reality of practicing the policy of additional educational support needs among teachers of deaf students in Qatar due to academic stage, as shown in table (7).

Table (7): Means and standard deviations to the impact "academic stage"

\begin{tabular}{|c|c|c|c|c|}
\hline Domains & Stages & No. & Mean & St. D \\
\hline \multirow[t]{4}{*}{ School policy } & Primary & 20 & 3.50 & .522 \\
\hline & Prep & 16 & 3.54 & .301 \\
\hline & High school & 19 & 3.65 & .222 \\
\hline & Total & 55 & 3.57 & .377 \\
\hline \multirow[t]{4}{*}{ Team in charge } & Primary & 20 & 3.55 & .585 \\
\hline & Prep & 16 & 3.55 & .323 \\
\hline & High school & 19 & 3.71 & .172 \\
\hline & Total & 55 & 3.61 & .406 \\
\hline \multirow[t]{4}{*}{ Curriculum } & Primary & 20 & 3.51 & .590 \\
\hline & Prep & 16 & 3.52 & .310 \\
\hline & High school & 19 & 3.60 & .365 \\
\hline & Total & 55 & 3.54 & .442 \\
\hline \multirow{4}{*}{$\begin{array}{l}\text { Professional } \\
\text { development }\end{array}$} & Primary & 20 & 3.59 & .536 \\
\hline & Prep & 16 & 3.57 & .300 \\
\hline & High school & 19 & 3.65 & .215 \\
\hline & Total & 55 & 3.61 & .378 \\
\hline School support for & Primary & 20 & 3.59 & .455 \\
\hline
\end{tabular}




\begin{tabular}{|l|l|l|l|l|}
\hline family and student & Prep & 16 & 3.47 & .388 \\
\cline { 2 - 5 } & High school & 19 & 3.55 & .204 \\
\cline { 2 - 5 } & Total & 55 & 3.54 & .362 \\
\hline \multirow{7}{*}{ Total } & Primary & 20 & 3.55 & .516 \\
\cline { 2 - 5 } & Prep & 16 & 3.53 & .289 \\
\cline { 2 - 5 } & High school & 19 & 3.63 & .166 \\
\cline { 2 - 5 } & Total & 55 & 3.57 & .358 \\
\hline
\end{tabular}

Table (7) indicates ostensible variance in the means and standard deviations for the reality of practicing the policy of additional educational support needs among teachers of deaf students in Qatar because of the different categories of academic stage; to convey the statistical differences between the means, one-way analysis of variance used according to table (8).

Table (8): One-way variance analysis for the impact of academic stage to the reality of practicing the policy of additional educational support needs among teachers of deaf students in Qatar

\begin{tabular}{|c|c|c|c|c|c|c|}
\hline Domains & Source & $\begin{array}{l}\text { Sum of } \\
\text { Squares }\end{array}$ & $\begin{array}{l}\text { D. } \\
\text { freedom } \\
\mathrm{S}\end{array}$ & $\begin{array}{l}\text { Mean of } \\
\text { squares }\end{array}$ & F-value & $\begin{array}{l}\text { Sig. } \\
\text { level }\end{array}$ \\
\hline \multirow[t]{3}{*}{ School policy } & $\begin{array}{l}\text { Between } \\
\text { groups }\end{array}$ & .247 & 2 & .123 & .866 & .427 \\
\hline & $\begin{array}{l}\text { Within } \\
\text { groups }\end{array}$ & 7.414 & 52 & .143 & & \\
\hline & Total & 7.661 & 54 & & & \\
\hline \multirow{3}{*}{ Team in charge } & $\begin{array}{l}\text { Between } \\
\text { groups }\end{array}$ & .312 & 2 & .156 & .944 & .396 \\
\hline & $\begin{array}{l}\text { Within } \\
\text { groups }\end{array}$ & 8.607 & 52 & .166 & & \\
\hline & Total & 8.919 & 54 & & & \\
\hline
\end{tabular}




\begin{tabular}{|c|c|c|c|c|c|c|}
\hline \multirow{3}{*}{ Curriculum } & $\begin{array}{l}\text { Between } \\
\text { groups }\end{array}$ & .092 & 2 & .046 & .229 & .796 \\
\hline & $\begin{array}{l}\text { Within } \\
\text { groups }\end{array}$ & 10.446 & 52 & .201 & & \\
\hline & Total & 10.538 & 54 & & & \\
\hline \multirow[t]{3}{*}{$\begin{array}{l}\text { Professional } \\
\text { development }\end{array}$} & $\begin{array}{l}\text { Between } \\
\text { groups }\end{array}$ & .071 & 2 & .036 & .243 & .785 \\
\hline & $\begin{array}{l}\text { Within } \\
\text { groups }\end{array}$ & 7.641 & 52 & .147 & & \\
\hline & Total & 7.713 & 54 & & & \\
\hline \multirow{3}{*}{$\begin{array}{l}\text { School support } \\
\text { for family and } \\
\text { student }\end{array}$} & $\begin{array}{l}\text { Between } \\
\text { groups }\end{array}$ & .123 & 2 & .061 & .461 & .633 \\
\hline & $\begin{array}{l}\text { Within } \\
\text { groups }\end{array}$ & 6.940 & 52 & .133 & & \\
\hline & Total & 7.063 & 54 & & & \\
\hline \multirow[t]{3}{*}{ Total } & $\begin{array}{l}\text { Between } \\
\text { groups }\end{array}$ & .109 & 2 & .055 & .418 & .661 \\
\hline & $\begin{array}{l}\text { Within } \\
\text { groups }\end{array}$ & 6.805 & 52 & .131 & & \\
\hline & Total & 6.914 & 54 & & & \\
\hline
\end{tabular}

Table (8) indicates that there are no statistically significant differences at the significance level $(\mathrm{a}=0.05)$ in the reality of practicing the policy of additional educational support needs among teachers of deaf students in Qatar attributed to the academic stage in all domains and in the total instrument.

\section{Discussion}

1. The results showed that the reality of practicing the policy of additional educational support needs among teachers of deaf students in Qatar was of high rating. This may be attributed to the new methods and behaviors adopted by the Supreme Education Council of Qatar to encourage teachers of the deaf to adopt additional educational support in the 
education of the deaf because this policy improves their skills and level of achievement, this is manifested through modern educational trends adopted by the Supreme Education Council of Qatar, which believes that the teacher is essential and instrumental in the school and is an important factor of success in carrying out its mission and achieving its vision, goals and objectives; where the Council has recently held training programs for in-service teacher in collaboration with the best trainers and specialists in the field of teaching and learning for the pursuit of empowerment of teachers in the State of Qatar.

2. With respect to domains, the domain of team in charge ranked the first place, due to the importance of a multidisciplinary team that emerges in the first steps to discover and diagnose the case, along with preparation and implementation of individual educational plan. The domain of professional development ranked the second place, the researcher believes that it is necessary to pay attention to this domain because professional development is very important for teachers, which is not limited only to training the in-service teachers, but more attention should be locally and regionally paid to the participation of teachers in various seminars and conferences in the educational field of the deaf, , as well as supporting teachers to participate in scientific research through providing them with financial support to increase the level of scientific publishing in various international reviewed journals.

3. The results showed statistically significant differences in school policy and the team in charge and in the total score of the reality of practicing the policy of additional educational support needs among teachers of deaf students due to the impact of gender, where differences were in favor of males. This may be attributed to the nature of males' willing and love for show and prominence proving that they deserve to work and take responsibility before the supreme educational leaders so we find them more self-efficacy and influential than females in educational work. The males are persistently seeking to achieve their aspirations and get the managerial and leadership positions that make them more diligent and satisfied and participate more in decision-making.

4. The results showed that there were no statistically significant differences in the reality of practicing the policy of additional educational support needs among teachers of deaf students in Qatar due to the variables of years of experience and academic stage in all domains and in the total instrument. This may be attributed to the nature of the educational circumstances in the school, and the conditions associated with the teaching profession in terms of the nature of the relationship with administration, relationship with colleagues, or the nature of the profession of education of the deaf. Therefore, the statistically significant differences did not emerge in the reality of practicing the policy of additional educational support needs among teachers of deaf students in Qatar due to the variables of years of experience and academic stage. The current results differed with the study of Sedeeq(2010), which showed differences between female teachers of the deaf due to the variable of years of experience in favor of the more experienced.

\section{Recommendations}

In light of the findings, the researcher recommends the following: 


\section{MInstitute Macrothink}

International Journal of Learning and Development

ISSN 2164-4063

- The need to sensitize teachers of deaf students to the importance of utilizing additional educational support in the education of the deaf; as this awareness has a clear role in activating the partnership with a multi-disciplinary team and parents of deaf students, and improving the quality and development plans.

- Urging authorities to monitor the practice of the policy of additional educational support needs among teachers of deaf students; because of its positive impact on improving the education of the deaf and to ensure the development and quality in schools.

- Conducting further studies on the reality of the practice of the policy of additional educational support needs among teachers of deaf students in Qatar through taking other variables such as the number of training sessions, and the teacher's way of thinking.

\section{References}

Al-Rashidi, Khaled\& Al-Ziq, Issam (2009).The impact of a training program on the development of teaching competences of Science in-service teachers of the deaf in prep stage. Journal of Psychological and Educational Research, Menoufia University,24 (1), 99-141.

Rifai, Tahra (2005). Assessment of the competencies required for teachers of students with hearing disability in Aden. A paper submitted to the Conference of the Arab Special Education: Reality and Hope, University of Jordan, Amman, Jordan.

Al-Rayes, Tariq. (2006). Theoretical study about the bi-lingual and bi-cultural: philosophy and strategies. A paper submitted to the Seventh Conference of the Arab Union, Cairo, Egypt.

Sedeeq, Lena. (2010). Proposed training program for the development of competency of female teachers of hearing-impaired students to teach the subject of reading in the first three grades of primary stage in Jeddah inclusion schools. Journal of the Faculty of EducationAin Shams University - Egypt, 34 (4): 437-481.

Aqel, Samir. (2012). Teaching for students with hearing disabilities. Amman: Dar Almaseera.

Issa, Ahmed. (2001). A suggested teaching strategy based on illustrated sign for enhancing adequacy of teaching chart of scientific concepts and developing inclinations of deaf pupils primary stage towards in science. Unpublished MA Thesis, University of Menoufia, Egypt.

Issa, Ahmad and Obaydat, Yahya. (2010). The effectiveness of auditory-verbal rehabilitation program and its relationship to the auditory discrimination and sequential auditory memory among a sample of children with electronic cochlea in Jeddah. Banha University, Journal of the College of Education, 20 (81): 224-265.

Supreme Education Council of Qatar (2009).Additional support policy.Qatar.

Morsi, Ashraf. (2013). The effectiveness of various density of visual stimuli in the computer programs on academic achievement and a tendency towards it among hearing impaired 


\section{Macrothink}

International Journal of Learning and Development

ISSN 2164-4063

2016, Vol. 6, No. 3

students in prep stage. Journal of Arab Studies in Education and Psychology, Saudi Arabia, 42 (2), pp 11-59.

Al-Nahas, Amal (2004).Assessment of educational programs for deaf students in Jordan from the perspective of principals, teachers, parents, with development proposal.unpublished $\mathrm{PhD}$ thesis, Amman Arab University, Amman, Jordan.

Angelides, P andAravi, C. (2007). A comparative Perspective on the Experiences of Deaf and Hard of Hearing Individuals of Students at Mainstream and Special Schools.American Annals of the Deaf, 151(5): 476-487.

Cannon, J. (2010). Effectiveness of Computer - based Syntax program in Improving the Morph syntax of Students who are Deaf, Hard Hearing.Educational Psychology and Special Education Dissertation. Georgia University, 63, U. S. A.

Combs, D. (2004).Framework for Scaffolding Content Area Reading Strategies.Middle School Journal, 36(20): 13-20.

Hallahan, L. Kauffman, W and Marteinez .(2005). Learning Disabilities Characteristics and Effective Teaching, second edition, Published .Inc.

Lipscomb, L., Swanson, J., West, A. (2004). Scaffolding.In M. Orey (Ed.), Emerging perspectives on learning, teaching, and technology. Retrieved September 18, 2009, from http://projects.coe.uga.edu/epltt/

Luckner, L. Muir, G. Howell, J, Sebald, A and young, J. (2005) an Examination of the Research and Training Needs in the Field of Deaf. Education American Annals of the Deaf 105(4): 358-368.

Taylor, et, al. (2008). Targeted Search of the Nature and Types of Services Provided Appropriate for the Visually Impaired from the Viewpoint of Students, Teachers. Journal of the future Britain,(125): 201-204..

\section{Copyright Disclaimer}

Copyright for this article is retained by the author(s), with first publication rights granted to the journal.

This is an open-access article distributed under the terms and conditions of the Creative Commons Attribution license (http://creativecommons.org/licenses/by/3.0/). 